\title{
Information System Strategic Planning for Department of Housing and Settlement Region in the Jakarta Provincial Government - Indonesia
}

\author{
Jarot Sembodo Suroso, Harisno, Tuga Mauritsius", and Agung Setyawan \\ Information Systems Management Department, Bina Nusantara Graduate Program, Master of Information Systems Management, \\ Bina Nusantara University, Jl. Syahdan No. 9, Jakarta 11480, Indonesia
}

\begin{abstract}
This research was conducted in the Unit Pengelola Rumah Susun-UPRS (Flats Manager Unit) in Jakarta Provincial Government and based on the existence of problems strategic planning of information systems. The purpose of this study is to provide a proposal of Information System Strategy and Management Information System for UPRS. The strategic planning of the information systems on research was conducted using the method of Ward and Peppard. The IS strategic planning in the UPRS which is proposed in this research is hope to be used to integrate each business process and IS system which is connected to the Jakarta Smart City. IS is needed with the competent human resources to manage the IS/IT of the UPRS to increase the service quality to the flat occupants and to increase the employees productivity in implementing their job functions.
\end{abstract}

Key words: E-government, information system strategic planning, ward and peppard framework.

\section{Introduction}

With the development of the world of Information Technology, both Information System (IS) and Information Technology (IT) play an important role in improving organization's strategic advantages/competitiveness. The management of IT is greatly needed to increase the success in achieving organization's objectives and to ensure the safety and accuracy of strategic information effectively by managing IT assets [1]. Managing the IS technology is not only done by private company, but public company also needs to manage their IS technology asset to ensure that their vision and mission is achieved effectively and efficiently, hence increasing their service to the community.

Unit Pengelola Rumah Susun-UPRS (Flats Manager Unit) is a unit under the Unit Kerja Perangkat DaerahUKPD (Regional Area Work Unit) in Jakarta Provincial Government based on the Regulation of the Regional Special Province of Jakarta No. 5/2016 on the Establishment and Composition of the Region Special Province of Jakarta. Their main task and function is managing public residential flats based on the Governor of the Province of Jakarta Capital Special Region's Regulation No. 351/2016 on the Establishment, Organization and Work Flow management Unit Housing Project.

UPRS has the function to provide housing for low income people and relocated program people. Housing which is manage by the UPRS are public residential flats which are build by the Department of Housing and Settlement Region of the Jakarta Provincial Government using the Local Government Budget (APBD-Anggaran Pendapatan dan Belanja Daerah) or from the Corporate Social Responsibility (CSR) activities. The management of each inhabited public residential flats is conducted by the UPRS according to the Jakarta Provincial Governor's Regulation No. 351/2016 regarding the formation, organization and work procedure of the public residential flat's management.

The UPRS public residential flat service business process consist of the registration process, occupant candidate's requirement validation, placement of prospective occupants to flat unit, services, data collection and financial administration of flat occupants, policing flat occupants and report preparation. The current IS utilization in the UPRS is only used to increase the effectiveness and efficiency of UPRS's operational activities but is not yet used to upgrade the

\footnotetext{
*Corresponding author: tmauritsus@,binus.edu
} 
services to the Jakarta Provincial people. The IS in the UPRS is not integrated to one another. Each of the 13 location of public residential flats has their own IS to provide services to their own occupants. Therefore this condition is not effective and efficient to the provision of service to the occupants. Databases which are not yet integrated can cause inconsistency of data, which can lead to problems in the data making process and reporting. The current IS condition in the UPRS is not yet used maximally and there is no planning for the development of IS in the UPRS.

The IS strategic planning in the UPRS which is proposed in this research is hope to be used to integrate each business process and IS system which is connected to the Jakarta Smart City application manage by the Department of Communication, Information and Statistic of the Jakarta Provincial Government. It is hoped that data will be more consistent and the operational activities in the UPRS will be more effective and efficient and hence providing disclosure of information to the public of Jakarta.

Identification of the problems that occur in UPRS based on previous research is as follows:

(i). Strategic planning of information systems is needed in an organization to support and assist the implementation of the tasks, responsibilities and functions as well as to achieve their goals. With the absence of information systems strategic, an organization will have difficulties in achieving their objectives. UPRS currently does not have an information systems strategic planning portfolio, and based on previous research this will make UPRS difficult in achieving their objectives [2-4].

(ii). Strategic planning is required to design and improve information systems in the future, so that organization can have a proper information system to help the organization achieve its objectives. UPRS currently does not have information system applications that can be used by UPRS to support the implementation of UPRS's duties. The application of information systems is required to support UPRS in carrying out the duties and achieve its objectives [2].

(iii). A division is needed in an organization that specializes on IS/IT, so that the development of IS/IT in an organization can be organized and developed properly. UPRS currently does not have a special division that deals with the development of IS/IT hence the IS/IT needs in UPRS is not available [4].

\section{Literature review}

Strategic planning based on the Ward and Peppard method is divided into two stages, input stage and output stage. Input stage contains the identification and analysis of internal and external conditions and the condition of IS internal and external to the organization where the input stages will be taken into consideration in determining the strategic plan of IS. Output stages produces physical documents based on the results of the strategic plan of IS input stages. Physical Document Management Strategies strategic plan in the form of IS, Business Strategy, and evaluation of business strategy and management.

\subsection{PEST analysis}

This analysis is used to identify the general environmental conditions of the organization. This identification is carried out from the aspects of the Political, Economic, Social and Technological.

(i) Political

Analysing the political factors which can affect the organization.

(ii) Economy

Analysing the current and upcoming economical condition factors which can affect the progress and the strategy of the organization.

(iii). Social Analysing the social factors which focus on the occupants' and employees' appraisal which can affect the strategy of the organization.

(iv). Technology

Technological changing factors that can affect the strategy of the organization.

\subsection{SWOT analysis}

SWOT analysis is an analysis environment based on four aspects: Strengths, Weaknesses, Opportunities and Threats.

(i). Strengths

Strength is the quality owned by the organization in obtaining their objectives. Strength can be tangible or intangible. It can be the expertise, quality and the loyalty of employee, high financial resources, free from any kind of debt and so forth.

(ii). Weaknesses

Weakness is something that prevents an organization in obtaining their objectives. Weakness can decrease the chance of organization's success. Weaknesses can be in the form of low quality of employees, low financial ability and so forth. 
(iii). Opportunities

Opportunities comes from the external environment's condition that be optimized by the organization in planning and doing their strategy in obtaining their objectives. Organization can achieve competitive advantage by utilizing the opportunities available. Opportunities can arise from competitiveness, the industries, government and technology.

(iv).Threats

Threat comes from the external environment's condition that threatened the reliability and advantages of an organization's business. Threats can affect the livelihood of an organization. For example uncomfortable working atmosphere, technological changes, and so forth.

\subsection{Critical Success Factor (CSF)}

CSF analyses the main factors that determine the organization's business development. It is very important for a thorough understanding of the business. CSF aims to attain the objectives and strategies and to emphasize the priority activities [5].

\subsection{Value Chain Analysis}

Value Chain is carried out to map the entire work process within the organization. It is mapped into two categories of activity, namely primary activities and support activities. An example of the value chain analysis can be seen in Fig. 1.

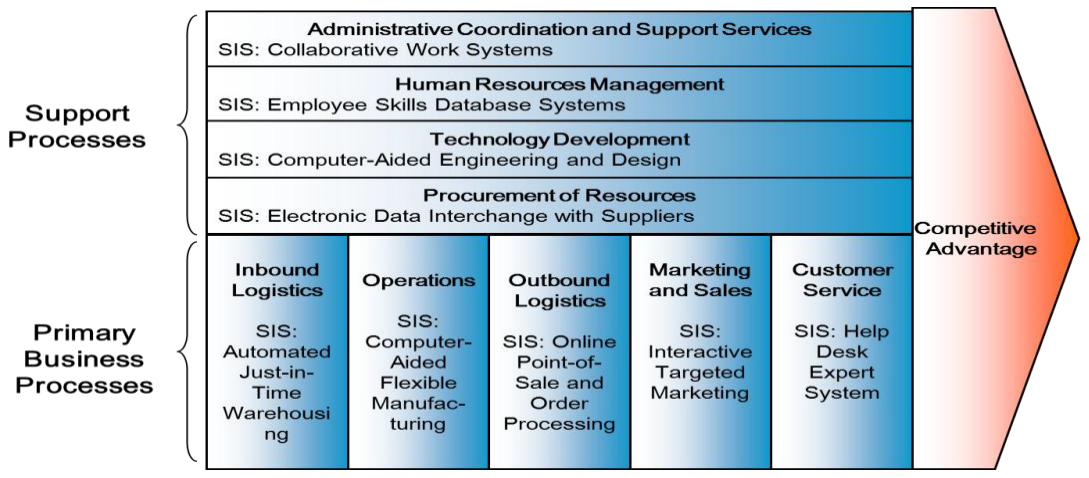

Fig. 1. Value Chain Analysis.

McFarlan Strategic Grid is used to map IS applications based on its contribution to the organization. Mapping is done in four quadrants (strategic, high potential, key operation, and support). The result obtained shows the role of each IS application is the organization and its future development [6]. An example of the McFarlan Strategic Grid can be seen in Figure 2.

\begin{tabular}{|c|c|c|}
\hline \multirow{2}{*}{$\begin{array}{l}\text { Strategic impact } \\
\text { of existing } \\
\text { system } \$\end{array}$} & $\begin{array}{l}\text { Support } \\
\text { Applications which improve } \\
\text { management and performance } \\
\text { but which are not critical to the } \\
\text { business. } \\
\text { e.g. Time recording }\end{array}$ & $\begin{array}{l}\text { Turnaround } \\
\text { Applications which may be of } \\
\text { future strategic importance. }\end{array}$ \\
\hline & $\begin{array}{l}\text { Factory } \\
\text { Applications which are critical to } \\
\text { sustaining existing business. }\end{array}$ & $\begin{array}{l}\text { Strategic } \\
\text { Applications which are crucial } \\
\text { for future success. }\end{array}$ \\
\hline GH & & $\begin{array}{l}\text { e.g. Computer-Integrated } \\
\text { Manufacturing }\end{array}$ \\
\hline
\end{tabular}

Fig. 2. McFarlan Strategic Grid. 


\section{Method}

The case study begins with an overview of formulation and identification of internal and external business environment and the environment of internal and external information systems of UPRS. An analysis of the IS needs in UPRS is then conducted through the IS strategic planning using the Ward and Peppard method's framework [2] which can be seen in Figure 3. Data are collected through literature study available from books and journals, interviews with the leader in UPRS, observation, documentation and the distributions of questionnaires to the UPRS employees.

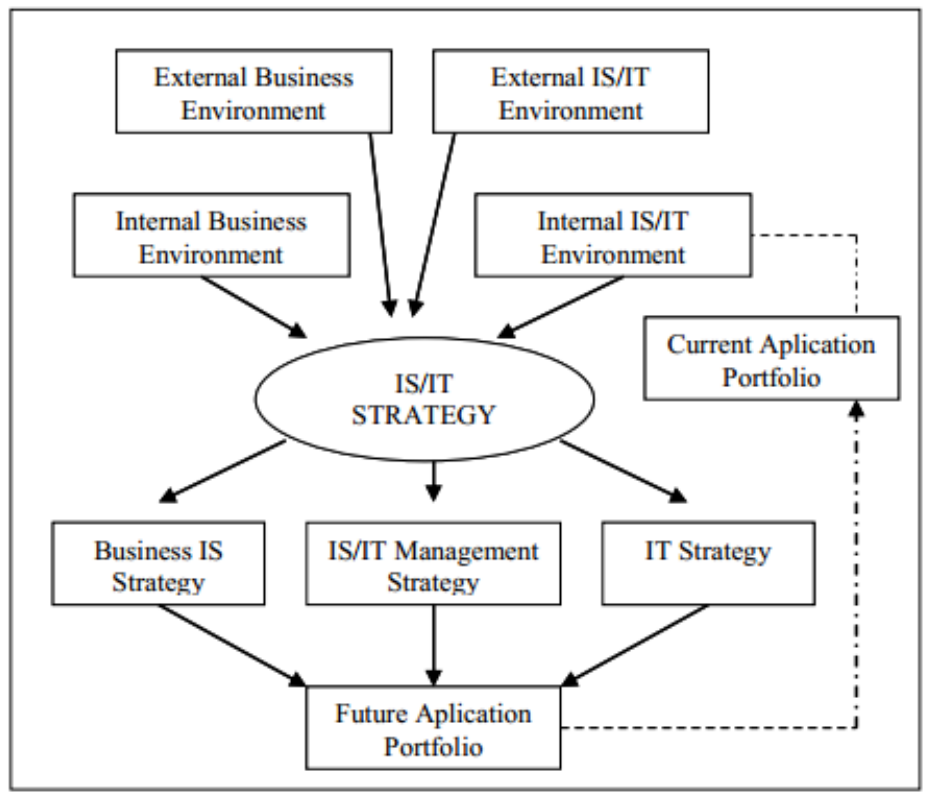

Fig. 3. Ward \& Peppard method's framework [2].

\section{Results and discussion}

\subsection{PEST analysis}

(i). Political factors

As one of the Regional Working Unit (UKPD) in the Provincial Government of Jakarta, UPRS have a regulatory basis as a reference in implementing their function. Regulations related to UPRS are as follows:

- Jakarta Governor Regulation number 111/2014 concerning the Mechanism Occupancy of Public Residential Flats' rents. These regulations govern the management of public residential flats, specify the tenants, manage kiosk on the ground floor and to curb residential area that is not in accordance with regulations. This regulation requires UPRS to work professionally so that the need for a system that helps UPRS in managing their modest public residential flats rental in a professional manner so that public residential flats' management can be effective, efficient and accountable.

- Regulation of the Governor of the Province of Jakarta Capital Special Region number 351/2016 on the Establishment, Organization and Work Flow Management Unit Housing Project. This regulation specifies the duties of employees in UPRS Cipinang. Given these rules, the scope of work of employees UPRS Cipinang are regulated and restricted in accordance within the rules. These regulations should be used by the UPRS's employees as much as possible. By limiting the scope of the job function of the employee, it will maximize their job function to achieve UPRS's vision and mission.

- Jakarta Governor Instruction number 131/2016 on Optimizing the Management of Public Residential Flat in Jakarta. This instruction instructs other agencies to participate in the management of Public Residential Flat Rent. UPRS cannot manage their own subsidized Public Residential Flat because of the complex problems in Public Residential Flat, either from residents or the infrastructure's quality of the Public Residential Flat. Therefore, this instruction instructed the relevant agencies to participate and manage subsidized Public Residential Flat. 
UPRS should be able to maximize the Governor Instruction because with the involvement of other agencies the management of Public Residential Flat can be optimized.

(ii). Economic Factors

Having a large amount of Local Government Budget (APBD), the UPRS can plan their budget of maximally. The increase in prices can not affect the UPRS in providing the management needs and public residential flat repairmen budget due to the fact that Jakarta Provincial Budget can become self-sufficient for the UKPD.

(iii). Social Factors

The occupants of public residential flat are mostly relocated/slum realignment residents which needs different treatments for each residents. The occupants also need assistance and empowerment because most of them have lost their jobs due to the relocation, while living in public residential flat needs rent money.

(iv). Technological factors

The current information system used in UPRS is only Microsoft office applications. With the increase in number of public residential flats, an integrated information system is needed. An integrated information system will support the management of public residential flats with the increase of amount of work load.

\subsection{SWOT Analysis}

(i). Improve the facilities subsidized apartment units

(ii). Improve the quality of service to the community

(iii). Develop Information Systems needed by Public Residential Flat

(iv). Marketing Public Residential Flat dwelling units for common low income people.

(v). Increase cooperation with other agencies and the private sector to empower citizens Public Residential Flat.

\subsection{CSF Analysis}

The CSF analysis can be seen in Table 1.

Table 1. CSF Analysis

\begin{tabular}{|c|c|c|c|c|}
\hline Objecti ves & $\begin{array}{l}\text { Critical Success } \\
\text { Factors }\end{array}$ & Indicators & Strategy & Needs SI \\
\hline \multirow{3}{*}{$\begin{array}{l}\text { Occupants towers } \\
\text { serve citizens well }\end{array}$} & \multirow{3}{*}{$\begin{array}{l}\text { Increased citizen } \\
\text { satisfaction } \\
\text { occupants towers }\end{array}$} & \multirow{3}{*}{$\begin{array}{l}\text { The level of citizen } \\
\text { satisfaction } \geq 80 \%\end{array}$} & $\begin{array}{l}\text { Facilitate access to } \\
\text { services citizens }\end{array}$ & E-Service \\
\hline & & & $\begin{array}{l}\text { Improve } \\
\text { communication with } \\
\text { citizens }\end{array}$ & E-News \\
\hline & & & $\begin{array}{l}\text { Streamline the } \\
\text { handling of } \\
\text { complaints of citizens }\end{array}$ & E-Disposition \\
\hline $\begin{array}{l}\text { Having data } \\
\text { processing with IS }\end{array}$ & $\begin{array}{l}\text { Increased data } \\
\text { processing } \\
\text { functions with IS }\end{array}$ & $\begin{array}{l}\text { Data processing } \\
\text { functions IS } \geq 50 \%\end{array}$ & $\begin{array}{l}\text { Developing } \\
\text { applications IS }\end{array}$ & $\begin{array}{l}\text { E-Rusunawa } \\
\text { HRIS } \\
\text { E-Assets } \\
\end{array}$ \\
\hline $\begin{array}{l}\text { Provides } \\
\text { information for } \\
\text { prospective } \\
\text { residents rusunawa }\end{array}$ & $\begin{array}{l}\text { The increasing } \\
\text { interest in } \\
\text { prospective } \\
\text { residents } \\
\text { rusunawa }\end{array}$ & $\begin{array}{l}\text { The number of } \\
\text { applicants } \geq 50 \%\end{array}$ & $\begin{array}{l}\text { To develop means and } \\
\text { complete information } \\
\text { to prospective rusu } \\
\text { nawa residents }\end{array}$ & Website Rusunawa \\
\hline $\begin{array}{l}\text { Reducing the } \\
\text { number of } \\
\text { violations }\end{array}$ & $\begin{array}{l}\text { Minimi zing } \\
\text { abuses rusunawa }\end{array}$ & $\begin{array}{l}\text { The number of } \\
\text { violations of } \leq 50 \%\end{array}$ & $\begin{array}{lll}\begin{array}{l}\text { Provide } \\
\text { media }\end{array} & \text { reports } & \text { to } \\
\text { citizens } & & \end{array}$ & E-Aduan \\
\hline
\end{tabular}

\subsection{Value Chain Analysis}

Based on interviews with informants, the main activities to value chain UPRS are as follows: 
(i). Inbound Logistics: Selection Apparatus State Civil Servants (ASN-Aparatur Sipil Negara) and Other Services Provider Individual (PJLP).

(ii). Operations: Service Flats, Flats Management.

(iii). Outbound Logistics: Disposition of UPRS employees to follow up flat occupants' complaints, demography services, repair services unit, Security Services and Sanitary Service.

(iv). Sales and Marketing: Facility received by the flat occupants.

(v). Services: The rental payment, settlement, security, cleanliness, orderliness and repair unit.

As for the supporting activities consist of:

(i). Infrastructure: Organizational Structure, Local Government Budget (APBD) of Jakarta Province and Flats.

(ii).Human-Resource Management Training, the State Civil Apparatus (ASN), Other Services Provider Individual (PJLP) Administration, PJLP Technician, PJLP Safety and Hygiene.

(iii). Technology Development: The Internet and Wifi.

(iv).Procurement: Tools hygiene, electronics \& mechanics tools, security tools, stationery office (ATK-Alat Tulis Kantor), office facilities and means of enforcement.

\subsection{McFarlan strategic grid}

Based on discussions with sources and analysis, the application portfolio of future IS UPRS can be seen in Table 2 .

Table 2. IS application portfolio for UPRS in the future.

\begin{tabular}{c|l|l|}
\cline { 2 - 3 } High & Strategic & High Potential \\
\cline { 2 - 3 } & e-News & e-Assets \\
& e-Service & e-Aduan \\
& e-Rusunawa & Website Rusunawa \\
\cline { 2 - 3 } Low & Keyperational & Support \\
\cline { 2 - 3 } & e-Disposition & HRIS \\
& & MS Office \\
\cline { 2 - 3 } & Low & High
\end{tabular}

The proposed information system for UPRS can be seen in Table 3.

Table 3. The proposed IS application for UPRS

\begin{tabular}{llll} 
No. & $\begin{array}{l}\text { Information } \\
\text { Systems }\end{array}$ & $\begin{array}{l}\text { Year Of } \\
\text { Develop }\end{array}$ & Category \\
\hline 1 & Website Rusunawa & 2018 & High potential \\
\hline 2 & e-Rusunawa & 2018 & Strategic \\
\hline 3 & HRIS & 2019 & Support \\
\hline 4 & $e$-Assets & 2019 & High potential \\
\hline 5 & $e$-Service & 2020 & Strategic \\
\hline 6 & $e$-News & 2020 & Strategic \\
\hline 7 & $e$-Disposition & 2021 & Key operational \\
\hline 8 & $e$-Aduan & 2021 & High potential \\
\hline
\end{tabular}

To evaluate the acceptance of the proposed IS strategies; questionnaires were given out using the Technology Acceptance Model (TAM). The TAM model consist of four dimensions which are perceived ease of use, perceive usefulness, attitude towards using and behavioural intention to use. Questionnaires were given out to 28 samples, where only 24 respondents responded to the questionnaires. The respondents were UPRS employees that will use the proposed IS in the future.

Based on the questionnaire result, it can be concluded that the proposed IS is well accepted by the respondents. Most respondents responded positively to the proposed IS. These are the following explanations:

(i). Perceived ease of use

In the perceived eased of use dimension most of the respondents responded "agree" and "strongly agree" to the questions given. This means that the respondents realize that the IS proposed is easy to use and can help UPRS employees in doing their functions. 
(ii).Perceived usefulness

In the perceived usefulness dimension, most of the respondents responded "strongly agree" to the questions given. This proves that the proposed IS is believed to be useful in providing services to the flat occupants and in increasing the productivities of UPRS employees.

(iii).Attitude toward using

In the attitude toward using dimension most of the respondents responded "agree" that the use of IS is a good idea and accepted the proposed IS.

(iv).Behavioural intention to use

In the behavioural intention to use dimension, most of the respondents responded "agree" in utilizing the IS proposed and will use the IS proposed to support their function in the UPRS.

\section{Conclusion}

Based on the analysis and business IS strategic planning in the UPRS of Department of Housing and Settlement Region of Jakarta Province, it can be concluded that: There are some obstacles in the UPRS regarding the IS such as UPRS does not have an IS which can help UPRS to do their job functions, the absence of IS that can present data that is integrated and accurate, the absence of automatic dissemination of information to the flat occupants, such as information regarding rent and arrears, and other important information available, the absence of IS strategic planning that can be used as guidance for future IS development in the UPRS and the absence of a specific human resource which is assigned to manage IS and IT in the UPRS. Therefore IS is needed with the competent human resources to manage the IS/IT of the UPRS to increase the service quality to the flat occupants and to increase the employees productivity in implementing their job functions. Supports area also needed from the board of managers in the Department of Housing and Settlement Region of Jakarta Province to support in terms of policy and budget making so that the development of IS in the UPRS becomes a priority. This is due to the fact that IS is needed to accommodate the increase number of public residential flats and the flat occupants due to the on going relocation program.

\section{References}

1. L. M. Applegate, R. D. Austin, D. L. Soule. Corporate information strategy and management. Pennsylvania: McGraw Hill (2009). pp. 41-207

https://books.google.co.id/books/about/Corporate_Information_Strategy_and_Manag.html?id=DWfbGAAACAAJ\& redir esc $=y$

2. J. Ward, J. Peppard, Strategic planning for information systems. New Jersey: Wiley (2002). pp. 1-573 https://www.amazon.com/Strategic-Planning-Information-Systems-John/dp/0470841478

3. C. Slamet. Analysis of information security audit using iso 27001:2013 \& iso 27002:2013 at it division - $x$ company, in Bandung, Indonesia. [Online] from http://www.insikapub.com/index.php/vol01-no01-july-2012?id=26 (2012). [Accessed on July 30 2017]

4. A. Cassidy. A practical guide to information systems strategic planning. Florida: Auerbach Publications (2005). pp. 1-22, https://www.amazon.com/Practical-Information-Systems-Strategic-Planning/dp/0849350735

5. K. C. Laudon, J. P. Laudon. Sistem informasi manajemen, mengelola perusahaan digital. [Management information systems, managing the digital firm]. Jakarta: Salemba Empat (2004). pp. 45-52. [in Bahasa Indonesia]. http://library.um.ac.id/free-contents/index.php/buku/detail/sistem-informasi-manajemen-mengelola-perusahaandigital-buku-1-kenneth-c-laudon-jane-p-laudon-38239.html

6. J. M. Bryson. Strategic planning for public and non-profit organization. NewYork: John Wiley \& Son (2011). pp. 81-317 https://www.wiley.com/en-

$\underline{\text { us} / \text { Strategic }+ \text { Planning }+ \text { for }+ \text { Public }+ \text { and }+ \text { Nonprofit }+ \text { Organizations } \% 3 \mathrm{~A}+\mathrm{A}+\text { Guide }+ \text { to }+ \text { Strengthening }+ \text { and }+ \text { Sustainin }}$ g+Organizational+Achievement $\% 2 \mathrm{C}+4$ th + Edition-p-9780470392515

7. K. E. Pearlson, I. C. S. Saunders. Strategic of management information system. Fourth Edition. New York: John Wiley \& Sons (2009). pp. 19-32.

https://books.google.co.id/books/about/Strategic_Management_of_Information_Syst.html?id=Zfw8nwEACAAJ\&re dir esc $=y$

8. E. Turban, R. K. Rainer, R. E. Potter. Introduction to information technology (8th ed.). New York: John Wiley \& Sons (2003). pp. 1-56. https://www.amazon.com/Introduction-Information-Technology-EfraimTurban/dp/0471347809

9. H. M. Jogiyanto. Sistem informasi strategik untuk keunggulan kompetitif [Strategic information system for competitive advantages]. Yogyakarta: Andi (2005). pp. 50-65. [in Bahasa Indonesia]. https://openlibrary.telkomuniversity.ac.id/pustaka/18833/sistem-informasi-strategik-untuk-keunggulankompetitif.html 
10. D. Urumsah. Jurnal Siasat Bisnis, 1,10: 123-140 (2005). [in Bahasa Indonesia]. http://journal.uii.ac.id/index.php/JSB/article/view/996/927

11. A. Peter. High, implementing world class IT strategy: How IT can drive organizational innovation. San Fransisco: Josey-Bass (2014) pp. 91-135. https://www.amazon.com/Implementing-World-Class-Strategy-

Organizational/dp/111863411X 